\title{
История транспорта
}

удК 625.143 .3

DOI: $10.46684 / 2687-1033.1 .19$

\section{Юрий Вячеславович Грдина - король русских рельсов}

\section{О.Д. Покровская}

Петербургский государственный университет путей сообщения Императора Александра I; 190031, г. Санкт-Петербург, Московский пр., д. 9

\begin{abstract}
АННОТАЦИЯ
Работа посвящена 75-й годовщине Победы в Великой Отечественной войне, вкладу сибирской науки и индустрии в нашу Победу.

Рассмотрена деятельность великого ученого, долгое время проработавшего в Кемеровской области, в Сибирском металлургическом институте (ныне - Сибирский государственный индустриальный университет, СибГИУ, г. Новокузнецк) Юрий Вячеславович Грдина, поистине - король рельсов, человек-легенда.

В 2021 г. исполнится 120 лет со дня рождения великого ученого. Сеть железных дорог России «соткана» из его рельсов. Отражена не только профессиональная деятельность Грдины - ученого, но и раскрыта его многогранная личность как творческого человека, увлекавшегося живописью, фотографией, водным туризмом, шахматами, литературой.
\end{abstract}

Ключевые слова: рельсы; рельсовый прокат; Юрий Вячеславович Грдина; железнодорожный транспорт и черная металлургия в годы Великой Отечественной войны

\section{Yuri Vyacheslavovich Grdina - king of russian rails}

\section{Oksana D. Pokrovskaya}

Emperor Alexander I St. Petersburg State Transport University; 9 Moskovsky pr., 190031, Russian Federation

\begin{abstract}
The work is dedicated to the 75th anniversary of the Victory in the Great Patriotic War, the contribution of Siberian science and industry to our Victory.

The activities of the great scientist, who worked for a long time in the Kemerovo region, at the Siberian Metallurgical Institute (now Siberian State Industrial University, Siberian State Industrial University, Novokuznetsk) are considered. Yuri Vyacheslavovich Grdina, truly - the king of rails, a man of legend.

In 2021, the 120th anniversary of the birth of the great scientist will be celebrated. The railway network of Russia is woven from its rails

Reflected not only the professional activities of Grdina - a scientist, but also revealed his multifaceted personality as a creative person who was fond of painting, photography, boating, chess, literature.
\end{abstract}

Keywords: rails; rail rental; Yuri Vyacheslavovich Grdina; railway transport and ferrous metallurgy during the Great Patriotic War

\section{НЕСКОЛЬКО СЛОВ О ЧЕЛОВЕКЕ, ИМЯ КОТОРОГО - НА КАРТЕ РОССИИ}

Юрий Вячеславович Грдина (6 июля 1901 г. 14 ноября 1967 г.) - талантливый сибирский ученый, заслуженный деятель науки и техники РСФСР, лауреат Государственной премии, доктор технических наук, профессор, возглавлявший в течение тридцати лет кафедру металловедения и термической обработки Сибирского государственного металлургического института (ныне - Сибирский государственный индустриальный университет, СибГИУ) [1].

Профессор Ю.В. Грдина (рис. 1) жил и работал в г. Сталинске (так назывался тогда г. Новокузнецк) с середины 30-х гг. прошлого века до скоропостижной кончины в 1967 г. Это был период грандиозной индустриализации, военных лет, периода восстановления разрушенного хозяйства страны. Требовались неординарные личности, которые смогли бы поднять неподъемное. Грдина - один из них. Его имя говорит само за себя: ведь «Грдина» по-чешски значит «герой» [2].

Он всю свою жизнь посвятил проблемам качества транспортного металла - рельсам — главной продукции Кузнецкого металлургического комбината (КМК, ныне - Новокузнецкий металлургический комбинат, НКМК).

Его именем названа одна из городских улиц в Новокузнецке. От улицы Тольятти до Левого берега тянется аллея с елочками, березками, клумбами вдоль пятиэтажек, здесь гуляют семьи с детьми. На стенах домов указатели «Улица имени Ю.В. Грдины», появившиеся в 1968 г. Многие знают, что живут на улице имени ученого, некоторые даже добавляют: «Профессора!» [3]. 


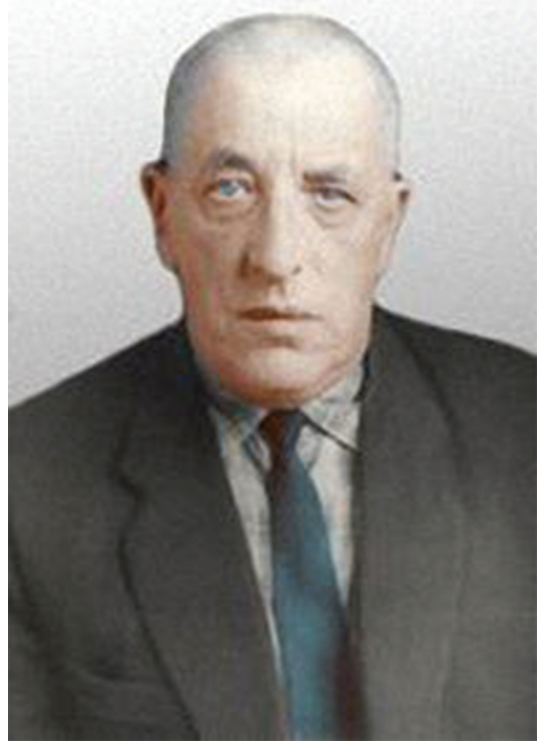

Рис. 1. Ю.В. Грдина [1]

Новокузнецк - уникальный город, промышленный центр Западной Сибири и, пожалуй, всей страны. Не буду говорить о количестве заводов и промышленных предприятий в нем, о месте Новокузнецка в экологическом рейтинге.

Одна из причин, по которой Новокузнецк знает вся страна, это его люди. Люди, которые выпускают транспортную сталь, востребованную в России и за рубежом.

\section{РОССИЙСКИЕ РЕЛЬСЫ СЕГОДНЯ}

Сегодня более 70 \% рельсового проката страны выпускается именно в Новокузнецке, на крупней- шем металлургическом гиганте «ЕВРАЗ», чье производство остается флагманом среди российских предприятий, его мощность составляет 950 тыс. т рельсов в год. Это более 20 видов рельсов по отечественным и зарубежным стандартам [4].

Первую кузнецкую сталь КМК выдал 19 сентября 1932 г., а 6 ноября - первые рельсы сибирского производства. Более восьми десятилетий производством рельсов в России исторически занимались лишь металлургические комбинаты, расположенные в Новокузнецке и Нижнем Тагиле (НКМК и НТМК). Например, все трамваи и метропоезда в стране ходят по рельсам, сделанным на НКМК. В структуре компании «ЕВРАЗ» комбинаты специализированы: НТМК занимается производством железнодорожных колес, а «ЕВРАЗ ЗСМК» - выпуском рельсов. Нужды ОАО «РЖД» в этой продукции кузнецкие металлурги обеспечивают сегодня в среднем на $70 \%$.

Первый этап масштабной модернизации производства был завершен в октябре 2010 г.: предприятие тогда освоило выпуск рельсов повышенной прямолинейности и длиной 25 м. В 2012 г. начался второй этап - строительство стана, позволяющего производить 100-метровые рельсы (рис. 2). Такие в России еще никто не делал, хотя их плюсы очевидны: благодаря увеличенной длине можно при прокладке железных дорог сократить количество стыков, что повышает безопасность движения и максимально допустимые скорости подвижного состава. До 2015 г. «РЖД» закупали такие рельсы исключительно за границей, в Австрии и Японии.

24 января 2013 г. на стане в Новокузнецке была прокатана первая сертификационная партия самых распространенных на железных дорогах Рос-

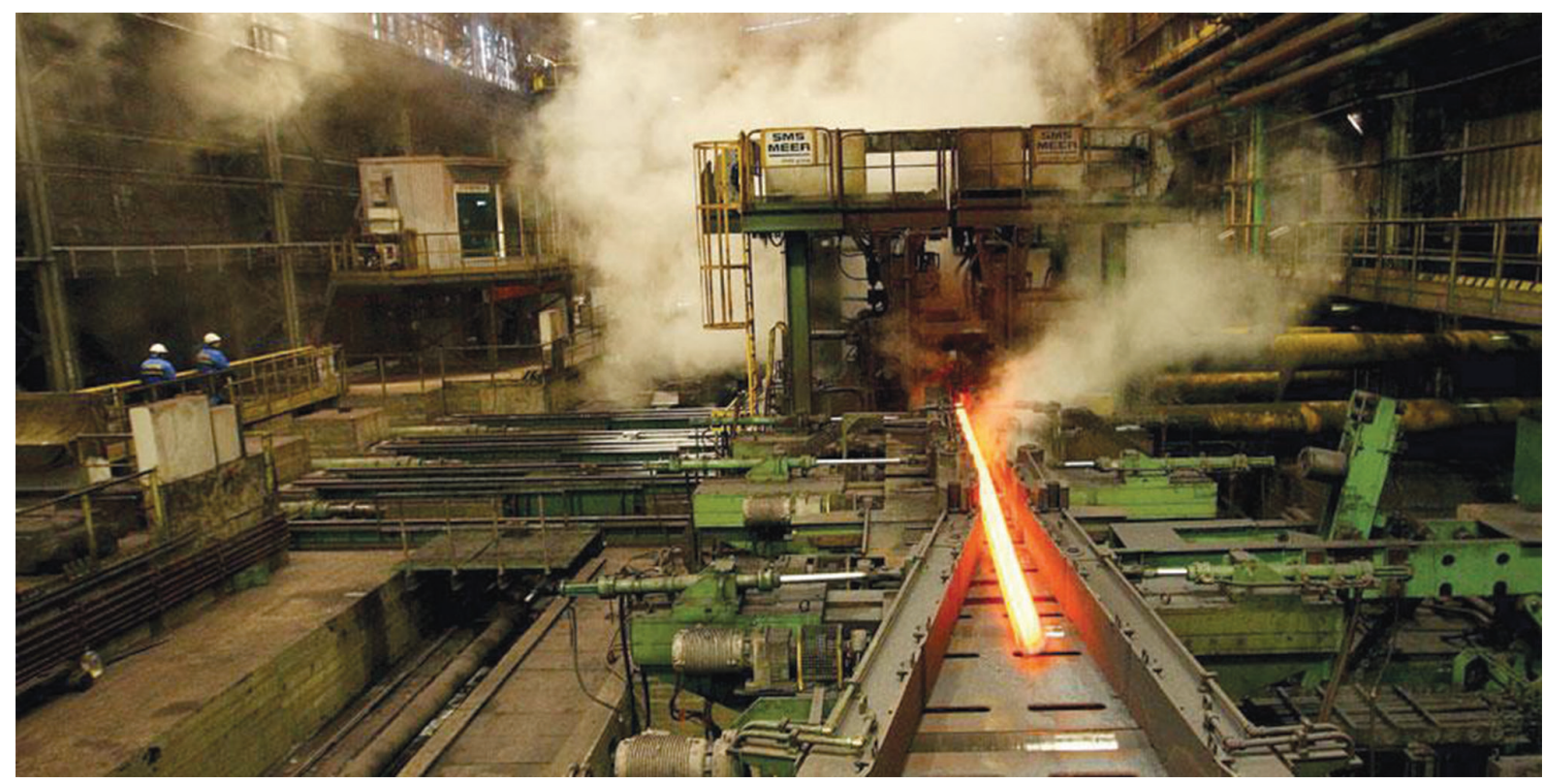

Рис. 2. Обжим заготовки под стометровый рельс в рельсобалочном цехе НКМК [5] 
сии рельсов типа Р65, изготовленных уже по новой технологии. А в ноябре 2014 г. сертифицированы рельсы Р65 по категории ДТ 350 (так называемые рельсы общего назначения дифференцированно термоупрочненные с прокатного нагрева). В декабре для РЖд было отгружено 10 тыс. т рельсов нового типа - правда, 25-метровых («стометровки» пришлось резать на четыре части). А уже в марте 2015 г. «ЕВРАЗ ЗСМК» поставил РЖД первую партию (около 15 тыс. т) стометровых рельсов.

Выйти на современный объем производства в 1 млн т проката в год предприятию удалось именно за счет рельсов - до 80 \% которых направлено в адрес ОАО «РЖД», включая широкую номенклатуру тех же Р65 (усовиковые и остряковые рельсы, контррельсы и т.п.). Еще 5-7 \% продукции - рельсы для метрополитенов, остальное - трамвайные рельсы и экспорт. Все это стало возможным благодаря труду и научным идеям Ю.В. Грдины - поистине короля русских рельсов $[4,5]$.

\section{линия жизни ю.в. ГРдИны}

Отец Юрия Вячеславовича, В.И. Грдина, учился в Томске, работал помощником начальника участка службы тяги Сибирской железной дороги на станции Нижнеудинск.

В 1911 г. Ю.В. Грдина поступил в Томское реальное училище. По окончании училища осенью 1918 г. принят в Томский технологический институт. Начиная с 1930 г., работал в качестве штатного доцента Томского государственного университета, читал курсы лекций по электротехнике, электрическим машинам, сопротивлению материалов и прикладной механике.

Юрий Вячеславович участвовал в создании Сибирского института черных металлов (СИЧМ, СМИ, ныне - СибгИУ, г. Новокузнецк), был заместителем директора, техническим директором (рис. 3).

В 1935 г. Юрию Вячеславовичу была присуждена ученая степень кандидата технических наук без защиты диссертации, по ходатайству соратника Ленина, тогда председателя Всероссийской комиссии по ВТО Георгия Кржижановского. Столь был велик его авторитет как ученого [6].

С начала строительства Кузнецкого металлургического комбината, КМК - Кузнецкстроя, научная деятельность Грдины и коллектива института направлена на решение проблем, связанных с пуском комбината: 6 ноября 1931 г. институт переведен на строительную площадку КМК.

В 1937 г. Сибирский институт черных металлов был преобразован в Сибирский металлургический институт (СМИ), а Грдина возглавил кафедру металловедения. С этого момента начинается его научная работа по термической обработке рельсов. Рельсовая проблема стала делом всей его жизни.

\section{РЕЛЬСЫ ГРДИНЫ - РЕЛЬСЫ ПОБЕДЫ}

Особенным периодом в жизни ученого стали годы Великой Отечественной войны. Ю.В. Грдина с группой сотрудников СМИ принимал участие в разработке технологических процессов производ-

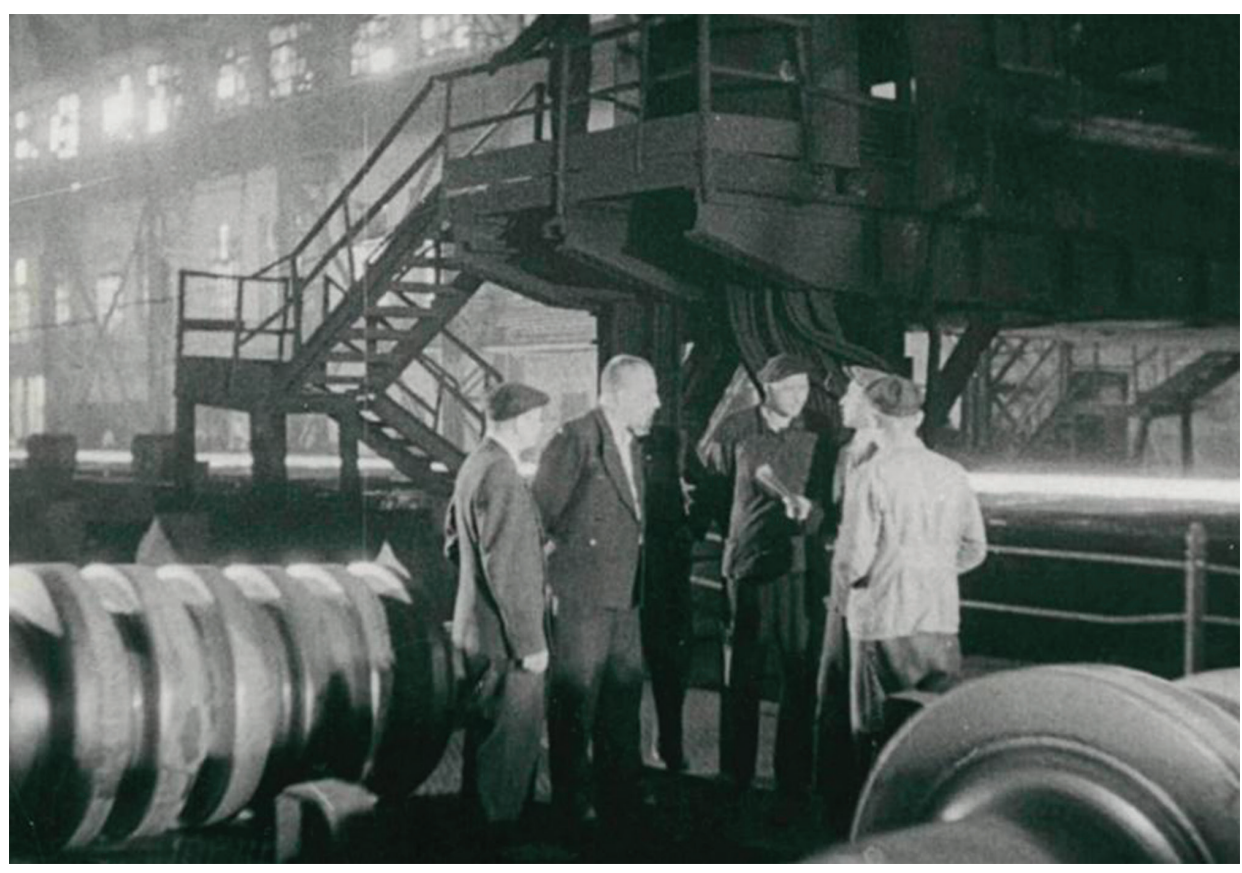

Рис. 3. Фото из архива: начальник цеха Б.Н. Жеребин и профессор П.Г. Рубин; Ю.В. Грдина (в центре) [9] 
ства оборонной продукции, и практически жил на заводе. Под его руководством на мартеновских печах КМК был освоен и налажен выпуск броневой стали, осуществлены прокатка и термообработка броневого листа. Фактически, по тем временам это была целая революция в металлургии.

Грдина вписал яркую страницу в историю обороны нашей страны. Тыл «воевал» точно так же, как солдаты на передовой. Только здесь были свои атаки и штурмы: «Все для фронта, все для Победы!». Москвой была поставлена задача освоения в короткий срок производства брони на КМК - качественной стали и проката для танков, самолетов и боеприпасов. Производство легированных сталей было развито преимущественно в южных и центральных районах страны, которые находились под оккупантами. Возникла необходимость срочно создать новую базу по производству легированного металла на востоке страны.

... Июнь 1941 г. Во втором мартеновском цехе КМК г. Сталинска работает группа ученых. Цель была одна: заставить большегрузные мартеновские печи варить броневую сталь, температура плавления у которой намного выше, чем у обычной стали. Во главе рабочей группы - Ю. Грдина и Н. Шубина, его жена, кандидат технических наук [7].

За 41 день была разработана эта технология. За плодотворную работу по выпуску оборонной продукции Грдина награжден орденом Трудового Красного Знамени.

Разработки Грдины и его группы имели огромное для обороны страны значение: 30 \% всей броневой стали и 50 \% броневого листа выпускал КМК г. Сталинска. А.Б. Берлин в книге «Сибирский металлургический институт. Дела и люди» писал: «На КМК выпускалось в годы Великой Отечественной войны 30 процентов всей броневой стали страны и 50 процентов броневого листа. В Кузнецкую броню «оделись" десятки тысяч танков и самолетов" [8]:

Всего, по данным А.Б. Берлина:

$\begin{array}{lll} & \text { по стране } & \text { в т.ч. из брони КМК } \\ \text { Танки } & 108 \text { тыс. } & 50 \text { тыс. } \\ \text { Самолеты } & 95 \mathrm{mыс.} & 45 \mathrm{mыc.} \\ \text { Снаряды } & 220 \mathrm{Mлн} & 100 \mathrm{Mлн} \text { [8]. }\end{array}$

Необходимо отметить, что к 1941 г. СибГиУ подготовил и направил для работы в промышленности 661 инженера шести основных металлургических специальностей. Выполняя задание правительства по обеспечению черной металлургии Кузбасса инженерно-техническими кадрами, институт направил только на КМК 457 своих выпускников. Всего за годы войны было подготовлено более 200 инженеров-металлургов.

Под руководством Ю.В. Грдины на КМК был освоен и налажен выпуск броневой стали уже в 1941 г. - через несколько месяцев после начала Великой Отечественной войны.
Однако не только танковая броня требовалась фронту. Необходимо было прокладывать новые железные дороги, имеющие оборонное значение. Большую работу по технологии термообработки броневого и транспортного металла проделал профессор Ю.В. Грдина, и созданная им в годы Великой Отечественной войны мощнейшая научно-практическая школа прорывных разработок, столь нужных фронту.

В связи с непрерывным увеличением грузооборота и напряженности на железных дорогах проблема стойкости рельсов и осей подвижного состава приобрела первостепенное значение в народном хозяйстве СССР. Ю.В. Грдина возглавил работы по изысканию новых марок стали и методов термической обработки рельсов и осей.

Важнейшим направлением его научной работы военных лет было исследование в области транспортного металла, а также исследование и освоение керченских мышьяковистых руд для изготовления рельсов.

Он разработал металловедческие основы термической обработки рельсов, позволяющие подобрать лучшую структуру и химический состав рельсовой стали. Проведена большая работа по технологии термической обработки рельсов в производственных условиях и созданию промышленных закалочных агрегатов.

В годы войны сибирский металлург разработал особую технологию обработки рельсов, итогом научных исследований стала докторская диссертация Юрия Вячеславовича, защита которой состоялась в 1942 г., а в 1943 г. ученый утвержден в звании профессора.

Рельсы, которые подвергались термообработке по технологии, разработанной Ю.В. Грдиной, были значительно прочнее и более устойчивы к износу. Производство новых рельсов экономило большое количество металла, который шел на нужды фронта [9].

Результатом многочисленных работ в течение длительного времени явилось строительство рельсотермического цеха для объемной закалки рельсов в масле на Нижнетагильском металлургическом заводе.

В 1945 г. Грдина награжден орденом Трудового Красного Знамени [3].

\section{МИРНОЕ ВРЕМЯ: НАУКА ВО БЛАГО МИРА}

После войны основная научная деятельность Грдины сосредоточилась в области транспортного металла.

В 1958 г. Юрий Вячеславович организует кафедру физики металлов и становится ее заведующим 
до 1967 г. Огромная эрудиция, исключительная работоспособность, ясный ум и талант ученого, горячий интерес ко всему новому, большая человеческая доброта - эти качества отмечали все, кто с ним работал.

Под его руководством было выполнено и защищено 10 кандидатских диссертаций, опубликовано 120 научных работ.

На протяжении тридцати лет научной работы Ю.В. Грдина читал курсы металловедения и термической обработки металлов, химико-термической обработки, специальных сталей и статистической обработки экспериментальных данных. Лекции он читал очень грамотно. Студентам приходилось записывать только идею, преподаватель преподносил ее легко и доступно. Студенты и коллеги называли его «Ю Вэ». В институте он вел себя вежливо, но очень сдержанно. Зато дома мог подолгу запросто общаться, разговаривая простым, незамысловатым языком [3, 7].

\section{ПРИЗНАНИЕ}

Термическая закалка рельсов в прокатном потоке оправдала себя, и государство высоко оценило заслуги ученого, в дальнейшем, в 1961 г., профессору Ю.В. Грдине было присвоено почетное звание «Заслуженный деятель науки и техники РСФСР».

В 1967 г. Ю.В. Грдине в составе группы специалистов присуждена Государственная премия СССР за разработку технологии, создание оборудования и внедрение в производство термической обработки железнодорожных рельсов. Это позволило повысить стойкость железнодорожных рельсов практически в два раза. Это был прорыв в развитии транспортного металла. В этой области он был специалистом мирового масштаба [2].

За работы в области транспортного металла Грдина был награжден двумя орденами Трудового Красного Знамени, орденом «Знак Почета», званием лауреата Государственной премии, за подготовку специалистов высшей квалификации и развитие отечественной промышленности - орденом Ленина и званием заслуженного деятеля науки и техники РСФСР, за выдающиеся научные успехи различными медалями.

\section{ТАЛАНТЛИВЫЙ ЧЕЛОВЕК ТАЛАНТЛИВ ВО ВСЕМ}

Не наукой единой жил этот выдающийся человек. Юрий Вячеславович любил рыбалку на таежных реках, прекрасно рисовал, импровизировал на пианино, играл на гитаре, мандолине, пел и сочинял сказки, увлекался шахматами, занимался фотографией, сам делал пластинки и бумагу.

У Грдины находилось время и для путешествий на Обскую губу, Тянь-Шань, в Горную Шорию, на Мрассу. Там он проводил часы отдыха на берегу, в палатке с ружьем и неизменной папиросой. Его любовь к рыбалке, к тайге была, видимо, какой-то отдушиной, возможностью в одиночестве на свежем воздухе что-то обдумать.

Ю.В. Грдина опубликовал научно-фантастическую повесть «Блистающий мир» (1963). Поводом к написанию книги стал роман Ивана Ефремова «Туманность Андромеды». Но, безусловно, повесть Ю.В. Грдины - это самостоятельное, мудрое и интересное произведение. «38-я звездная задерживалась...» - так начинается повесть «Блистающий мир». "Темный и пустой уголок галактики. И в нем затерянная песчинка - Земля. Разрушить это страшное одиночество... За пределами нашего островка рассеяны ликующие миры, на них должно ступить человечество...». В уста своего героя Ю.В. Грдина вкладывает следующие слова: «Хорошо, что космос бесконечен, и можно всегда, хотя бы мысленно, быть впереди» [7] (рис. 4).

В юго-восточной части Обской губы Карского моря есть Мыс Грдины. Он исследован в 1920 г. экспедицией Томского технологического университета и назван в честь магнитолога экспедиции.

\section{ВСПОМИНАЯ ГЕНИЯ...}

Читая воспоминания людей, близких или знакомых с Грдиной, находишь подтверждение того, что талантливый человек талантлив во всем: он написал фантастическую повесть, занимался водным туризмом (рис. 5), прекрасно играл на фортепиано, писал замечательные пейзажи, и, конечно же, был гениальным физиком, который знал о рельсах все.

Знакомые отмечали очень уважительное отношение профессора к людям любого ранга. К Грдине часто обращались за финансовой поддержкой, и он никому не отказывал. В кабинете профессора всегда стоял открытый сейф [7].

Интересны воспоминания Игоря Шубина, пасынка Грдины. На рабочем столе ученого стоял микроскоп, лежала кучка чистых листов, а под стеклом находились таблицы, пособие для термистов. Слева стояло фото И.П. Бардина - первого директора Кузнецкстроя, а справа - фото юного сына Вячеслава. «Это самое ценное, что я мог придумать на этом свете», - говорил Грдина о своем сыне. И.Ю. Шубин писал, что Юрий Вячеславович «личность масштабная, выдающийся ученый, незаурядный организатор науки и великолепный преподаватель", что и в быту он был человеком нео- 


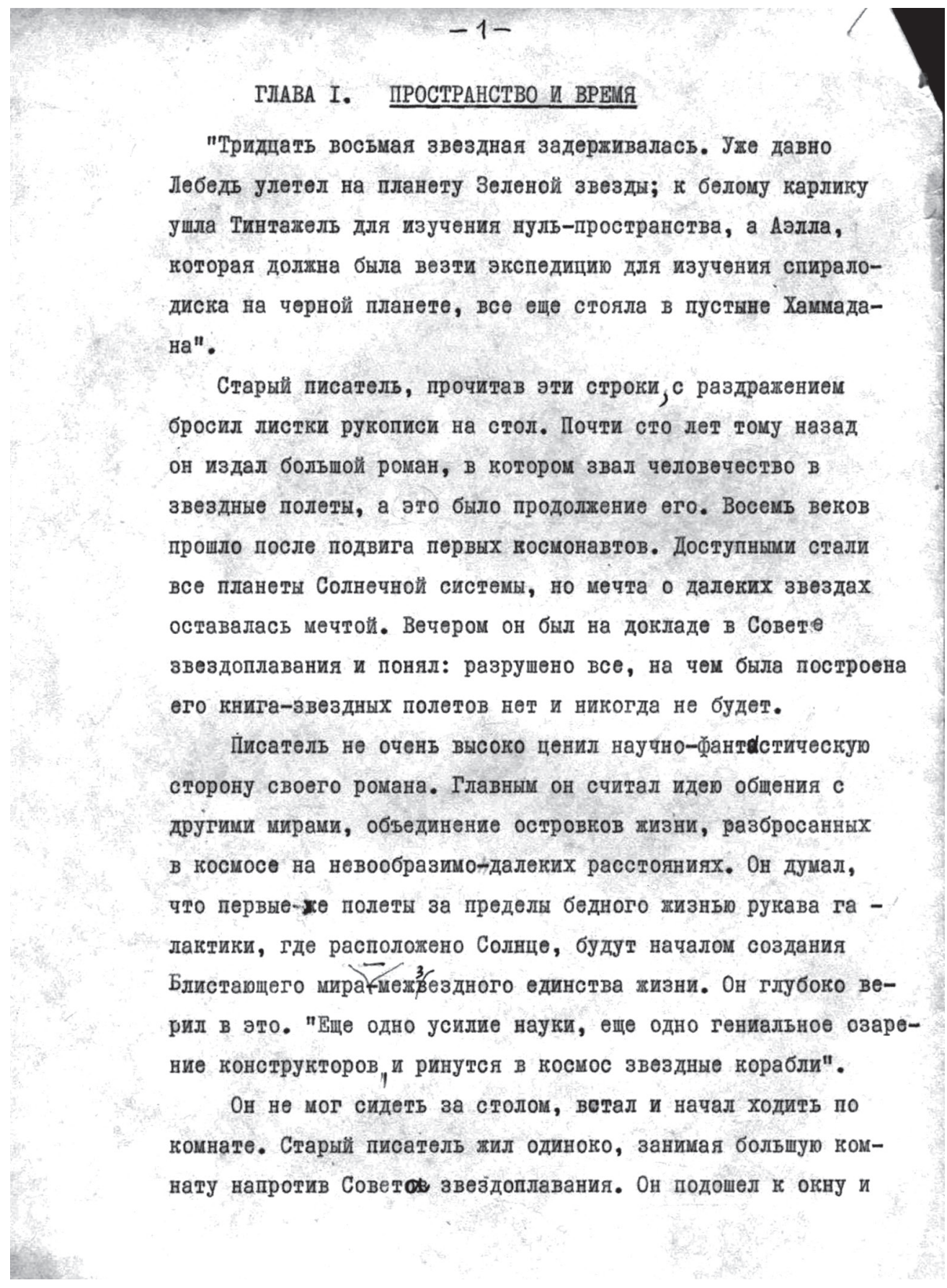

Рис. 4. Начало повести «Блистающий мир» [7]

быкновенным - увлекался фотографией и делал прекрасные ландшафтные и портретные снимки, любил праздники и ради детворы наряжался Дедом Морозом, а дом Грдины всегда был полон гостей и друзей. Традиционные сибирские пельмени были угощением [2].

"Я бы в первую очередь отметил ясность и могучую чистоту его мышления», - так отзывается о своем преподавателе Н.В. Лапин, выпускник СМИ 1954 г. [7]. "Я первый раз встретил человека, который мог так просто и доходчиво говорить о сложных и запутанных вещах. В 1957 году Грдину с группой ученых отправили в Англию. Я вдохновен- но прилетел к нему после его приезда с просьбой рассказать об Англии и поездке. Ведь именно тогда кто-то на встрече произнес ставшую известной фразу об «отие русских рельсов». Ничего такого он тогда мне не сказал. Только вздохнул: «Знаешь, Коля, плохого я там ничего не увидел, а про хорошее вряд ли напечатают...» [6].

Среди учеников Ю.В. Грдины - Н.М. Кулагин, ректор СибГИУ с 1988 по 2008 г.: «Первый набор кафедры физики металлов был объявлен в 1958 году. Нас в группе 25 человек, половина медалистов, потому что на эту специальность был самый большой конкурс. И сразу, на первом же курсе, Грдина 
нам сказал: «Это чисто научно-исследовательское направление, поэтому мы из вас будем делать ученыц», - вспоминает Н.М. Кулагин [10].

Прошлое продолжается в настоящем: «Самое важное, что Ю.В. Грдина для нас сделал, - это показал, как надо работать», - утверждает В.К. Афанасьев, заведующий кафедрой физики металлов и новых материалов СибГИУ. «Преданность науке была у него безусловная, фактически, он совершил трудовой подвиг. Хотя сейчас не говорят таких высоких слов, но это так!».

В.И. Люленков вспоминает о Ю.В. Грдине: «Юрий Вячеславович Грдина был не совсем обычный человек. В каком смысле? Он был высококвалифицированный профессионал, один из лучших в нашей стране рельсовик. Он первым, по сути дела, дал броневую сталь на Кузнецком комбинате.

Профессионализм у него был высочайший. Но Грдина был очень замкнутый человек. Ему трудно было сходиться с людьми, особенно с новыми, но, если он сходился, это была привязанность очень сильная. Была эпоха таких людей, которые были безмерно преданы работе, развитию промышленности. Таким был Грдина» [11].

Л.А. Балицкая: «Конечно, он - гений. Я с уверенностью могу сказать, что у нас в стране сегодня нет такого профессионала, каким был Ю.В. Грдина».

А.Б. Алалыкин, ныне лектор курса «Специальные стали», вспоминает: «Впервые я увидел Юрия Вячеславовича Грдину в 1954 году, когда он читал нам курс „Специальные стали“ в Сибирском металлургическом институте, а я слушал и затем сдавал ему экзамен. Это был очень крупный мужчина, ростом под метр девяносто. Позднее, когда мы уже общались в неформальной обстановке, он рассказывал, что в молодости гнул подковы.

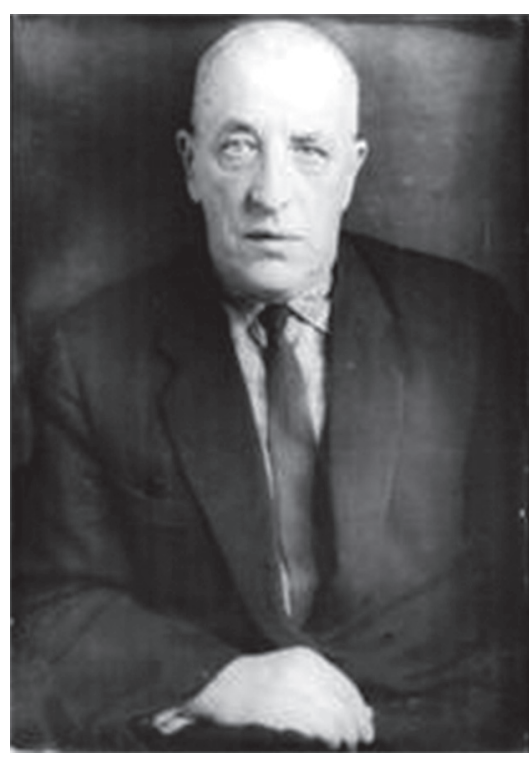

Рис. 5, 6. Юрий Вячеславович Грдина [7]
Как лектор Грдина очень запоминался: хорошо знал предмет и давал именно то, что надо, по специальности. „Неуды“ он ставить не любил, считал, что, как научил студента, так тот и сдает.

Как-то, помню, он заболел и попросил меня и еще одного молодого сотрудника принять за него экзамен. Сдавали человек 20 студентов, и мы поставили пять или шесть „неудов“ Но это присуще молодому преподавателю - ставить „двойки“ налево и направо. Это молодость. Потом он нас отругал. „Что вы наделали! Вам ничего нельзя поручить!“, - и больше уже никогда не доверял принимать экзамены.

„Рельсовая тема“ была любимой работой Ю.В. Грдины, ряд товарищей из Минчермета, железнодорожники, пара человек из тагила и Грдина получили за эту работу Государственную премию».

Г.М. Тов, профессор, Стэмфорд, США: «Ю.В. Грдина был самый выдающийся ученый. Равного ему нет. Он получил Государственную премию за очень важную для страны работу по закалке концов рельсов буквально перед смертью. Ему пытались мало выплатить, вызвали в горком и сказали: „Или бери то, что дают, или мы тебя накажем... “Обычно эти премии давали к 7 Ноября. Объявили, что дают премию, а 12 он умер.

Конечно, Грдина был очень эрудированный человек. Когда я пришла работать в институт, он мне сразу сказал: „Давайте готовить диссертацию вот по такой теме“. Я начала работать, ездила на конференции, но у нас было мало литературы, в основном литература была за границей. И он предложил: „Давайте возьмем тему попроще. Вы защититесь, а потом уже продолжите исследования в этом направлении“. Дело в том, что рельс имеет

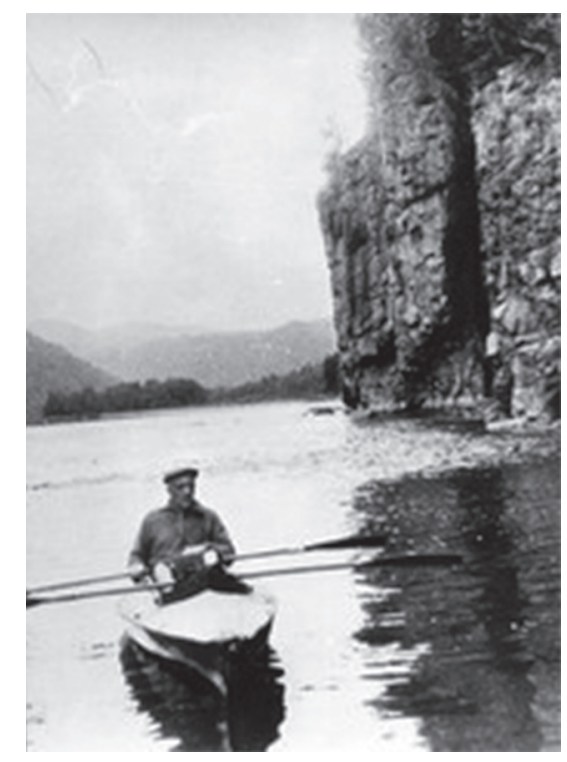


определенный срок службы, а концы его, то есть там, где он стыкуется с другими рельсами, изнашиваются быстрее. Так вот Грдина придумал, как закаливать отдельно кониы рельсов, чтобы многократно увеличить их срок службы. Это был большой прорыв в производстве качественных рельсов, стойкость их повысилась почти в два раза, и железные дороги, конечно, были довольны. Отношение Грдины к коллегам было хорошее, доверительное. Никогда никого не унижал, а это - признак сильного человека» [12].

\section{«ОТЕЦ РУССКИХ РЕЛЬСОВ »}

Жизнь и творчество Ю.В. Грдины вдохновляет заниматься наукой, увлекаться чем-то в жизни, совершать добрые поступки, иметь собственное мнение и не быть, как все.

«Гений oт Бога» - так вспоминают о Грдине. Имя на карте, новый рельсовый прокат, статьи в энциклопедиях... Как же много скрывается за этими строками: Юрий Вячеславович Грдина - поистине великий - человек, ученый, педагог. В 2013 г. вышла книга В.Е. Угрюмова «Ю.В. Грдина - отец русских рельсов» [7], название книги - это цитата из речи английских ученых в 1957 г. о человеке-легенде русского транспортного металла.

Результат научных достижений Грдины - строительство на заводах СССР термических отделений по предупреждению образования флокенов. Грдину приглашали работать в Америку, но он был патриотом своей страны. В личных встречах и статьях он ратовал за организацию АН СССР в Западной Сибири.

У Грдины была важная способность внедрять в производство свои идеи. Да и вся его жизнь - это сочетание выдающихся способностей и удивительных событий, которые не только проверяли масштаб этой личности, но и заставляли человека выкладываться «по полной». Профессора Ю.В. Грдину отличали огромная эрудиция, исключительная работоспособность, ум и большой талант.

«Могущество России Сибирью прирастать будет». Прирастать выдающимися учеными, новыми промышленными технологиями, научными идеями... Эти слова М.В. Ломоносова, похоже, никогда не утратят своей актуальности, равно как и люди из сибирской глубинки, российские ученые - свои таланты.

\section{ЛИТЕРАТУРА}

1. Грдина Юрий Вячеславович. Материал из Википедии свободной энциклопедии. URL: https://ru.wikipedia.org/wiki/ Грдина_Юрий_Вячеславович

2. Негода Т. Грдина значит «герой» // Кузнецкий рабочий. 2016. URL: https://kuzrab.ru/rubriki/obshestvo/grdina-znachit-geroy/

3. Угрюмов В. Отец русских рельсов // Кузнецкий рабочий. 2015. URL: https://kuzrab.ru/rubriki/obshestvo/otets-russkikh-relsov/

4. ЕВРАЗ ЗСМК увеличит объем производства 100-метровых рельсов. 2017. URL: https://vashgorod.ru/news/58411

5. Попов A. Кузнецкая металлургическая революция // Эксперт Сибирь. 2015. № 5 (439). URL: https://expert.ru/ siberia/2015/05/kuznetskaya-metallurgicheskaya-revolyutsiya/ media/preview/\#anchor-1

6. Михайлов С. Несколько слов о Юрии Грдине // Кузнецкий рабочий. 2007. URL: https://kuzrab.ru/publics/neskolko-slovo-yurii-grdine/
7. Ю.В. Грдина - отец русских рельсов / сост. В.Е. Угрюмов. Кемерово: ООО «Печатный двор Кузбасса», 2013. 453 с.

8. Берлин А.Б. Сибирский металлургический институт. Дела и люди. Новокузнецк, 1992. 225 с

9. Негода Т. Гремя огнем, сверкая блеском стали... // Кузнецкий рабочий. 2015. URL: https://kuzrab.ru/rubriki/obshestvo/ gremya-ognyem-sverkaya-bleskom-stali/

10. Эмих T. Ученый, Педагог, Человек! // Кузнецкий рабочий. 2011. URL: https://kuzrab.ru/publics/uchyonyj-pedagogchelovek/

11. Угрюмов В. Владимир Иванович Люленков: «Мы представители земного шара» // Кузнецкий рабочий. 2011. URL: https://kuzrab.ru/publics/vladimir-ivanovich-lyulenkov-mypredstaviteli-zemnogo-shara/

12. Угрюмов В. «Конечно, он - гений» // Кузнецкий рабочий. 2011. URL: https://kuzrab.ru/publics/konechno-on-genij/

\section{REFERENCES}

1. Grdina Yuri Vyacheslavovich. From Wikipedia, the free encyclopedia. URL: https://ru.wikipedia.org/wiki/Грдина_Юрий_ Вячеславович (In Russian).

2. Negoda T. Grdina means "hero”. Kuznetsk Worker. 2016. URL: https://kuzrab.ru/rubriki/obshestvo/grdina-znachit-geroy/ (In Russian).
3. Ugryumov V. Father of Russian Rails. Kuznetsk Worker. 2015. URL: https://kuzrab.ru/rubriki/obshestvo/otets-russkikh-relsov/ (In Russian).

4. EVRAZ ZSMK will increase the production of 100-meter rails. 2017. URL: https://vashgorod.ru/news/58411 (In Russian). 
5. Popov A. Kuznetsk metallurgical revolution. Expert Siberia. 2015; 5(439). URL: https://expert.ru/siberia/2015/05/kuznetskaya-metallurgicheskaya-revolyutsiya/media/preview/\#anchor-1 (In Russian).

6. Mikhailov S. A few words about Yuri Grdin. Kuznetsk Worker. 2007. URL: https://kuzrab.ru/publics/neskolko-slov-o-yurii-grdine/ (In Russian).

7. Yu.V. Grdina is the father of Russian rails. / comp. V.E. Ugryumov. Kemerovo, Printing House of Kuzbass LLC, 2013; 453. (In Russian).

8. Berlin A.B. Siberian Metallurgical Institute. Cases and people. Novokuznetsk, 1992; 225. (In Russian).
9. Negoda T. Thundering with fire, sparkling with the brilliance of steel... Kuznetsk Worker. 2015. URL: https://kuzrab.ru/rubriki/ obshestvo/gremya-ognyem-sverkaya-bleskom-stali/ (In Russian).

10. Emich T. Scientist, Educator, Man! Kuznetsk Worker. 2011. URL: https://kuzrab.ru/publics/uchyonyj-pedagog-chelovek/ (In Russian).

11. Ugryumov V. Vladimir Ivanovich Lyulenkov: "We are representatives of the globe". Kuznetsk Worker. 2011. URL: https:// kuzrab.ru/publics/vladimir-ivanovich-lyulenkov-my-predstaviteli-zemnogo-shara/ (In Russian)

12. Ugryumov V. "Of course, he is a genius". Kuznetsk Worker 2011. URL: https://kuzrab.ru/publics/konechno-on-genij/ (In Russian).

\section{Об авторе}

Оксана Дмитриевна Покровская - доктор технических наук, доцент, профессор кафедры железнодорожные станции и узлы, начальник Центра информационно-аналитического сопровождения научной работы; Петербургский государственный университет путей сообщения Императора Александра I; 190031, г. Санкт-Петербург, Московский пр., д. 9; insight1986@inbox.ru.

\section{Bionotes}

Oksana D. Pokrovskaya - Doctor of Technical Sciences, Associate Professor, Professor of the Department Railway stations and nodes, Head of the Center for information and analytical support of scientific work; Emperor Alexander I St. Petersburg State Transport university; 9 Moskovsky pr., 190031, Russian Federation; insight1986@inbox.ru.

для цитиРовАНия: Покровская О.Д. Юрий Вячеславович Грдина - король русских рельсов // Техник транспорта: образование и практика. 2020. T. 1. Вып. 1-2. C. 118-126. DOI: 10.46684/2687-1033.1.19

FOR CITATION: Pokrovskaya O.D. Yuri Vyacheslavovich Grdina - king of russian rails. Transport technician: education and practice. 2020; 1 (12):118-126. (in Russian). DOl: 10.46684/2687-1033.1.19

Поступила в редакцию 2 мая 2020 г.

Received May 2, 2020

(ㄷ) О.Д. Покровская, 2020 